\title{
Perlindungan Perempuan dalam Hukum Islam di Indonesia (Analisis terhadap Hukum Perkawinan dan Kewarisan)
}

\author{
Abdul Jamil
}

\begin{abstract}
(
Abstract

In comprehending the quranic text and Hadits (prophet tradition) systematically. The position of women on marriage and legacy is getting sub-ordination. The men is positioned and symbolized as a superior because of his obligation and responsibility is considered bigger than the women. Recently, through contextual interpretation on gender justice dimension, treatment and placement of women position proportionally and parallelly with the men have become the frame and innovation paradigm of Islamic Law for the two fields. Through this innovation the discriminative treatment and the view of the unsuitable cultural construction for the women is expected to be corrected and open our eyes for the justice in which recently they are closed by the misled cultural symbol.
\end{abstract}

\section{Pendahuluan}

Tuntutan pemberdayaan perempuan tampaknya masih menjadi perhatian khusus, bahkan menjelang pemilu 2004 isu-isu gender menguat kembali menjadi komoditas politik, seperti pertambahan kuota $30 \%$ bagi calon legislatif perempuan. Dinamisasi tuntutan isu-isu gender (sekitar 1990-an) inilah kemungkinan menjadi pertimbangan awal perlunya kajian ulang terhadap hak-hak perempuan dalam wacana hukum Islam di Indonesia, sebab Undang-undang Peradilan Agama baru disahkan pada bulan Desember
1989 dan Kompilasi Hukum Islam (KHI) di Tahun 1990.

Tuntutan para pejuang gender akan kesetaraan antara perempuan dan laki-laki merupakan upaya untuk mendapatkan status yang sama dan kesempatan yang sama dalam merealisasikan potensinya sebagai hak-hak asasi.' Di bidang hukum, kesetaraan yang dimaksud adalah bagaimana peran perempuan agar memiliki peluang yang sama dalam mendukung hak dan kewajiban sebagai subjek hukum.

'Saparina Sadli, "Pemberdayaan Perempuan dalam Perspektif Hak Asasi Manusia" dalam Tapi Omas Ihromi DKK, Penghapusan Diskriminasi terhadap Wanita, Edisi pertama, Ctk. 1, (Bandung; Alumni, 2000). $\lim .8$ 
Secara konseptual, mengkaji hukum Islam di Indonesia tidak dapat dipisahkan dengan sistem hukum yang berlaku di Indonesia yang dipengaruhi juga oleh sistem hukum di dunia. Sebagaimana diketahui bahwa di dunia setidaknya ada lima sistem hukum, dan sampai saat ini Indonesia mengadopsi tiga dari lima sistem hukum tersebut, yaitu: (1) hukum Barat, (2) hukum Adat, dan (3) hukum Islam. ${ }^{2}$ Dalam praktiknya, ketiga sistem hukum tersebut tidak diadopsi secara mutlak sebab kondisi sosio-budaya hukum masyarakat Indonesia yang pluralis, majemuk dan multietnik tidak memungkinkan unifikasi ke dalam satu sistem hukum tertentu. Seperti halnya hukum Islam, sebagian kaedah hukumnya hanya ditransflantasikan ke dalam hukum perdata tertentu saja, di antaranya perkawinan, kewarisan, perbankan, wakaf dan shadaqah, demikian juga di bidang hukum pidana dan hukum tata negara.

Dalam wacana hukum Islam, kerancuan pengerian syariah dan hukum Islam masih sering terjadi. Secara etimologis, kedua term ini memiliki pengertian yang berbeda. Syariah mengandung pengertian lebih sempit, yaknihukum-hukum yang bersumber dari alQuran dan kitab hadits. Sedangkan hukum Islam mengandung pengertian lebih luas, selain bersumber dari al-Quran dan hadits juga ijtihad. Dengan demikian peraturan perundang-undangan yang dibuat oleh lembaga yang berwenang yang tidak bertentangan dengan syariah termasuk pengertian hukum Islam. Dalam pendapat Ahmad Sukardja disebut dengan Siyasah Syariah. $^{3}$

Untuk melihat bagaimana perlindungan hak-hak perempuan dalam hukum Islam di Indonesia maka dapat dilihat bagaimana hakhak tersebut diatur, dijamin dan dilindungi dalam hukum perkawinan dan kewarisan. Sejak diundangkannya Undang-undang No. 1 Tahun 1974 tentang perkawinan, Undangundang No. 7 Tahun 1989 tentang Peradilan Agama, dan Inpres No. 1 Tahun 1991 tentang Kompilasi Hukum Islam, serta Undangundang No. 7 Tahun 1989 tentang Peradilan Agama, perempuan telah memiliki kedudukan yang setara dengan kaum laki-laki bahkan peraturan-peraturan tersebut cenderung lebih melindungi hak-hak perempuan, khususnya dalam masalah perceraian. ${ }^{4}$

\section{Pandangan Hukum Islam (klasik) terhadap Perempuan}

Perempuan dalam perjalanan sejarah, sejak jaman orang-orang Yunani, Romawi, Undang-undang Hammúrabi, Yahudi sampai masa Jahiliyah mempunyai sejarah yang buruk, yang dipengaruhi oleh sikap kebiasaan yang

${ }^{2}$ Baca Mohammad Daud Ali, Hukum Islam Pengalar llmu Hukum dan Tafa Hukum Islam di indonesia, Ed. 5. Ck. Ke lima, (Jakarta: Raja Grafindo Persada, 1996), hlm. 188.

${ }^{3}$ Ahmad Sukardja, Piagam Madinah dan Undang-Undang Dasar 1945: kajian PerbandinganTentang Dasar Hidup Bersama dalam Masyarakat Yang Majemuk (Jakarta: UI Press, 1995), hlm. 9-10, dan lihat juga Muhammad Daud Ali, Hukum Islam. op. cit. him. 44

"Hadari Djenawi Taher, Pokok-Pokok Pikiran dalam U. U. Peradilan Agama (Jakarta: Alda, 1989), hlm.12

${ }^{5}$ Baca Haya binti Mubarok, "Mausu'ah AJ-Mar'atul Muslimah" yang ditejemahkan oleh Amir Hamzah Fachrudin, Ensiklopedi Wanita Muslimah (Jakarta: Darul Falah, 1418 H). him.5-13. 
buruk masyarakat terhadap perempuan pada waktu itu. ${ }^{5}$ Sikap pandang yang demikian diwariskan turun-temurun dari generasi ke generasi. Sebagai contoh wanita dalam pandangan orang-orang Yunani sebagai najis dan kotoran dari hasil perbuatan setan, wanita dipandang sebagai orang yang tidak mempunyai harga diri dan martabat. Di masa jahiliyah perempuan juga tidak mempunyai tempat yang terhormat sehingga perempuan dipandang sebagai objek bukan subjek. bahkan perempuan bisa menjadi objek warisan apabila ditinggal mati suaminya dan anaknya menghendaki untuk itu. ${ }^{6}$ Ringkasnya perempuan tidak mempunyai kedudukan yang sempurna sebagai makhluk ciptaan Tuhan yang sempurna untuk memakmurkan bumi. Pandangan inilah yang mempengaruhi pandangan hukum terhadap perempuan.

Peran agama khususnya Islam mempunyai andil besar sebagai pemutus mata rantai terhadap perlakuan yang tidak adil demikian. Islam merubah kebiasaan buruk dan pandangan yang negatif terhadap perempuan. Ajaran Islam menempatkan posisi perempuan baik dalam hal ibadah maupun hukum sebagai subjek bukan objek. Islam mendudukkan lakilaki dan perempuan setara. Kesetaraan ini terlihat terutama dalam visi dasar kemanusiaannya.?

Dalam ajaran syariah (setelah Nabi Muhammad SAW diangkat menjadi nabi dan rasul) kedudukan kaum peremplian yäng tadinya secara turun-temurun dianggap sebagai objek, - sebagai contoh dalam hal perkawinan yang berhak menentukan maupun yang menerima mahar adalah orang tuanya sebagai wali, - dirubah menjadi, baik yang menentukan jumlah maupun yang menerima mahar adalah hak perempuan yang menikah, demikian juga dalam hukum kewarisan yang tadinya perempuan sebagai objek warisan, dirubah posisinya menjadi subjek penerima warisan dari keluargany $a^{B}$ atau kerabat yang meninggal dunia.

Dalam hukum perkawinan (klasik), hak mentalak ada pada laki-laki. Ketentuan ini dipengaruhi oleh adat kebiasaan sebelum lslam atau ma'sa jahiliyah yang seenaknya saj: memperlakukan perempuan termasuk hak untuk merujuk istrinya sebelum masa 'iddah habis. Tindakan laki-laki seperti itu tidak semata-mata untuk mencabut talaknya yar.g sudah terlanjur jatuh dan merasa kasihan melihat bekas istri dan anak-anaknya menderita, tetapi ia ingin kembali kepada istrinya dan mentalak yang kedua kalinya dan seterusnya agar perempuan (bekas istrinya) terkatung-katung, tidak dapat menikah dan tidak bebas. Islam membatasi penjatuhan talak hanya dua kali dan penjatuhan talak yang ketiga berarti talak yang terakhir. Untuk talak ketiga bekas suami dapat kembali apabila bekas istri yang dicerai itu sudah menikah dengan laki-laki lain. ${ }^{9}$ Islam tidak me: . ghapus

${ }^{6}$ Ibid., hlm. 5-9

${ }^{7}$ Masdar F. Mas'udi, "Perempuan dalam Wacana Keislaman," dalam Perempuan dan Pemberdayaan: Kumpulan Karangan untuk Menghomati Ulang Tahun ke-70 lbu Saparina Sadli, Penyunting Smita Notosusanto dan E. Kristin Poenwandari, Ctk. Pertama, (Jakarta: Obor, 1997), hlm. 59

${ }^{8}$ lbid., hlm. 59, baca juga Haya binti Mubarok Al-Barik, op. cit., hlm. 9-14

${ }^{9}$ J.N.D. Anderson, Hukum Islam di Dunia Moderen (Islamic Law in the Modem World), Penterjemah Machnun Husain, Edisi Revisi, Ctk. 1, (Yogyakarta: Tiara Wacana Yogya, 1994), hlm. 50-51 
hak talak tetapi yang dilarang oleh Isfam adalah perlakuan suami tanpa batas dalam mentalak istrinya. Para ahli hukum Islam (klasik) sepakat bahwa hitungan talak dan hak talak tetap ada pada suami (laki-laki), akan tetapi masalah penggunaannya para ahli hukum Islam hampir tidak mempersoalkannya, sehingga talak hampir tidak ada kendalinya. Sebab seperti diketahui di kalangan kelompok Sunni, pengucapan talak tidak diberikan batasan, bahkan dalam madzhab Hanafi dikatakan ucapan talak yang dikatakan pada waktu mabuk atau diancam pihak lain dianggap sah dan mempunyai akibat hukum. ${ }^{10}$

Terhadap persoalan talak ini para ahli hukum Islam (klasik) hanya membagi lafadI atau ucapan talak saja sehingga kapan saja dan di mana saja talak itu bisa jatuh. ${ }^{11}$ Jatuhnya talak tidak memandang sebab dan tempat, kalau suami merasa tidak puas dengan istri maka suami dapat dengan seenaknya saja menjatuhkan talak, bahkan yang sangat ekstim suami dapat seenaknya memperlakukan istrinya kalau ia suka, misalnya malam menikah pagi bisa saja bercerai dan lain sebagainya. Dengan demikian, persoalan cerai hanya semata-mata ada pada laki-laki, sebab perempuan (istri) tidak mempunyai hak untuk menjatuhkan talak. Semenderita apapun seorang perempuan (istri) dalam ruman tangganya, ia tetap tidak dapat menceraikan suaminya.
Persoalan lain dalam hukum perkawinan adalah perempuan hamil di luar nikah tidak boleh menikah meskipun dengan teman lakilaki berzinanya sampai anak dalam kandungan perempuan itu lahir Di sini perempuan sangat didudukkan pada derajat yang hina dan rendah, meskipun perberbuatan itu dilakukan suka sama suka, sementara lakilaki tidak menanggung resiko apapun. Resiko akibat hasil perbuatan zina itu-ditimpakan kepada perempuan serta anak yang akan dilahirkan. Apabila dilihat sanksi pidananya (dalam jinayah) di dalam surat an-Nur ayat (2) keduanya baik laki-laki maupun perempuan sama-sama kena hukuman cambuk. Dalam ayat (3), pezina itu tidak boleh menikah kecuali dengan teman berzinanya.

Apabila ditarik garis hukum dari kedua ayat (2 dan 3) di atas maka hukuman bagi pezina tidak hanya dijatuhkan kepada perempuan saja tetapi juga pada laki-laki pasangan berzinannya. Sedangkan perempuan yang hamil dari hasil hubungan zina diharamkan menikah dengan laki-laki mukmin lain kecuali dengan laki-laki pasangan berzinanya tersebut. Sanksi hukum demikian tentulah sangat tidak adil karena risiko hanya dibebankan pada perempuan secara sepihak sementara laki-laki pasangan berzinanya dibebaskan dari resiko (sanksi), padahal hubungan itu dilakukan atas dasär kesepakatan berdua atau suka sama

"ofbid., hlm. 63-65

"Cara menjatuhkan atau lafadl talak dalam figh ada beberapa istilah yaitu: talak sarikh (jelas) artinya ahwa suami jelas mengucapkan kepada istrinya, "kamu saya talak maka jatuhlah talak suami kepada istrinya;" yang kedua talak kinayah (sindiran), talak yang ucapannya hanya melalui sindiran, misalnya suami mengatakan kepada istrinya, engkau sekarang haram untukku, atau sekarang pulanglah kamu kepada orangtuamu dan lainlain. Sulaiman Rasjid, Fiqih Islam, Ctk. Kedua belas, (Jakarta: Attahirijah, 1955), him. 381, lihat juga Sudarsono, Pokok-Pokok Hukum Islam, Ctk. Pertama, (Jakarta: Rineka Cipta, 1992), hlm. 262, lihat juga Abdullah Djamali, Hukum Islam Asas-asas hukum Islam I, Hukum Islam II, Cłk. I, (Bandung: Mandar Maju, 1992), hlm. 95 
suka. Larangan menikah bagi perempuan hamil semata-mata menghukum si perempuan dan keluarganya, seolah-lah lakilakinya adalah kebal terhadap hukum.

Larangan pernikahan perempuan hamil akibat zina dengan laki-laki pasangan berzinanya akan mengakibatkan penderitaan perempuan dan keluarganya semakin berat dan berkepanjangan. Sebab kalau sianak itu lahir tanggung jawab merawat, membesarkan dan mendidik anak menjadi beban ibu dan keluarganya. Hal ini sudah barang tentu membutuhkan biaya (materi). Penderitaan ini masih ditambah lagi dengan cap negatif sosia! terhadap si anak sebagai anak haram.

Persoalan lain yang berkaitan dengan kedudukan perempuan adalah persoalan waris. Pandangan hukum Islam (klasik) dalam hal kewarisan kedudukan perempuan juga dalam posisi yang lemah dibanding laki-laki. Karena keturunan perempuan dapat ditutup oleh laki-laki dan keturunannya. Sebagai contoh misalnya $A$ (Laki-laki) menikah dengan $B$ (perempuan) $A$ dan $B$ mempunyai dua anak, $C$ (laki-laki) dan D (perempuan), $C$ juga menikah dengan $E$ (perempuan) dan mempunyai satu anak $F$ (perempuan), demikian juga $D$ menikah dengan $G$ (laki-laki) dan mempunyai anak $H$ (perempuan). Misalnya $D$ (anak perempuan) dari pasangan $A$ dan $B$ Tahun 2002 meninggal dunia, yang kemudian disusul oleh A (bapaknya) pada 2003, maka ahli waris $A$ adalah hanya dua orang yaitu $B$ (istri) dan $C$ (anak laki-laki), sedang $H$ (cucu perempuan) dari anak perempuan $D$ tidak berhak waris karena ditutup (mahjub) pamannya sendiri.

Secara ekstrim kasus tersebut di atas apabila dikembangkan, misalnya anak laki-laki yang bernama $C$ juga meninggal dunia lebih dulu yaitu pada 2001, maka ketika kakek $F$ dan $H$ yang bernama $A$ meninggal dunia pada 2003 ahli waris yang berhak hanya B selaku istri dan $F$ (cucu perempuan) dari anak lakilaki (C). sedangkan $\mathrm{H}$ yang kedudukannya dalam pengertian kerabat (Qarabah) dalam surat an-Nisa ayat (7) adalah sama dengan $F$, tetapi bedanya $F$ dari keturunan laki-laki dan $H$ dari keturunan perempuan. $F$ diberi bagian warisan dari kakeknya $(A)$ karena dzawil furudl yang bagiannya lebih besar dari pada istrinya pewaris (B), sebab B selaku istri mendapatk:" 1/8 sedangkan satu cucu perempuan $(F)$ mendapatkan 1/2. Dalam pemecahan kasus waris ini terjadi radd (sisa harta), sebab tidak ada yang menghabisi harta waris (ashabah!.

Apabila ditelaah lebih jauh contoh kedia kasus di atas maka kedudukan $\mathrm{H}$ dalam garis hukum waris Islam (klasik) kedudukannya sangat lemah dan tidak setara (seimbang), karena ia cucu yang berasal dari keturunan perempuan yang dalam waris islam (faraid) disebut dengan istileh dzawil arham. Sebagaimana diketahui bahwa dalam hukum kewarisan Islam (klasik) golongan ahli waris apabila dilihat dari segi perolehan hak atas harta warisan ahli waris dibedakan menjadi tiga golongan yaitu: (1) dzawil is udl, (2) ashabah dan (3). dzawil amam. ${ }^{12}$ Kedudukan dzawil furudl dan ashabah sangat kuat karena

\footnotetext{
${ }^{12}$ Dzawil fundl adalah ahli waris yang mempunyai bagian-bagian tertentu sebagaimana disebulkan dalam al-Quran dan kitab al-Hadits, sedangkan ashabah ahli waris yang tidak ditentukan bagiannya akan mendapatkan ;isa setelah diambil dzawil furudl, dan dzawil amam adalah ahli waris yang mempunyai hubungan keluarga dengan pewaris, letapi tidak termasuk golongan dzawil funull dan ashabah. Ibid , hlm. 24-27.
} 
dia berasal dari keturunan laki-laki secara langsung, sedangkan kedudukan dzawil arham dalam hukum waris Islam dipandang sangat lemah sehingga selama ada dzawil furudl dan ashabah maka dzawil arham selamanya akan terhalang atau dengan kata lain dia tidak akan dapat bagian warisan kecuali apabila terjadi sisa harta waris $(\operatorname{Radd})^{13}$

Apakah dengan terjadinya radd dalam setiap kasus waris dalam hukum waris Islam dzawil arham akan mendapatkan bagian warisan yang ditinggalkan oleh pewaris? ternyata tidak setiap kasus radd ahli waris dalam golongan dzawil arham mendapatkan bagian waris. Sebab dalam hal terjadi kasus radd di kalangan para ahli hukum Islam (klasik) masih terjadi perbedaan pendapat, antara lain pendapat pertama, sahabat Ali apabila terjadi radd maka dikemalikan (diberikan) kepada ahli waris yang ada selain suami atai istri dengan perandingan besar kecilnya masingmasing. Penyelesaian kasus waris kedua di atas jika didasarkan pada pendapat Ali maka radd tersebut diberikan kepada $F$ (cucu perempuan), sehingga $F$ mendapatkan dua kali bagian, sementara $\mathrm{H}$ yang juga samasama cucu perempuan dari pewaris (A) tidak dapat bagian waris. Pendapat Ali ini diikuti oleh ahli hukum Islam yang lain seperti Imam Hanafi dan Imam Hambali. Pendapat kedua, sahabat Utsman, bahwa apabila terjadi radd maka diberikan kepada ahli waris yang ada termasuk kepada suami atau istri sehingga apabila kasus kedua di atas diselesaikan berdasarkan faham kedua maka radd tersebut diberikan kepada $B$ (istri) dan F (cucu perempuan) sedangkan $\mathrm{H}$ tetap tidak mendapat bagian, pendapat ini diikuti oleh Undang-undang Waris Mesir No. 77 Tahun 1943. Pendapat ketiga, sahabat Zaid bin Tsait, apaila terjadi radd menurut pendapat ini diberikan diberikan kepada selain alhi waris yang sudah ditentukan dalam a-Qur'an dan kitab al-Hadits. Pendapat ketiga ini diikuti oleh Imam Malik dan Imam Syafi'i. ${ }^{14}$

Penyelesaian kasus waris kedua di atas dalam hal terjadi radd karena masih terjadi perbedaan pendapat maka tentu saja setiap penyelesaian cucu perempuan dari jalur perempuan (dzawil arham) dalam hukum Islam (klasik) masih terjadi ketidakjelasan, sebab ia digantungkan terhadap penerimaan faham yang dianut dalam masyarakat di mana terjadinya kasus waris tersebut. Kalau masyarakatnya masih berpegang erat kepada faham sahabat Ali yang dikembangkan madzhab Hanafi dan Hambali dan pendapat Utsman maka cucu perempuan dari anak perempuan tidak akan dapat bagian warisan, kecuali masyarakat lingkungannya bermadzhab Maliki dan Syafii.

\section{Upaya Perlindungan Hak Perempuan dalam Hukum Islam di Indonesia}

Hak perempuan dalam hukum Islam di Indonesia dan di negara-negara Islam pada

\footnotetext{
"Radd terjadi apabila ada sisa harta warisan yang disebabkan karena tidak ada waris yang mewarisi harta waris (ashabah) tersebut, atau dengan kata lain, apabila terjadi jumlah bagian ahli waris kurang dari asal masalah, baca Ahmad Azhar Basyir, Hukum Waris Islam, edisi ke IX, (Yogyakarta: Fakultas Ekonomi Uil, 1990), hlm. 19-20
}

"Baca Ahmad Azhar Basyir, ibid. hlm. 19-21 
umumnya yang masih mempunyai persoalan kontreversi di kalangan pemeluknya adalah hukum keluarga yang secara spisifik adalah hukum perkawinan dan kewarisan. Oleh sebab itu sebelum membahas perlindungan hak perempuan dalam hukum Islam di Indonesia perlu Penulis singgung tentang pandangan perempuan dalam hukum keluarga di Indonesia secara umum. Hukum perkawinan dan kewarisan termasuk bagian dari hukum keluarga, sedangkan pandangan terhadap hak perempuan dalam kedua hukum tersebut di Indonesia apabila ditelaah secara teliti ternyata masih ada juga pengaruh adat dan kebiasaan dalam masyarakat. Pandangan kesetaraan terhadap hak perempuan kaitan dengan kedua hukum tersebut masih berbeda-beda sikap, hal ini dipengaruhi oleh struktur masyarakatnya.

Di Indonesia, corak struktur masyarakat yang pluralis (multi etnik) ternyata melahirkan hukum keluarga yang beragam. ${ }^{15}$ Secara garis besar dalam ilmu antropologi sosial sistem kekeluargaan dalam masyarakat dapat didasarkan atas sistem keturunan yang unilateral dan bilateral. Unilateral yaitu cara menarik garis keturunan ke atas hanya melalui penghubung laki-laki saja (unilateral patrelinial), atau hanya melalui penghubung perempuan saja (unilateral matrelinial). Sedangkan billateral atau juga disebut parental adalah cara menarik garis keturunan dalam masyarakat yang menghubungkan dirinya baik dari garis bapak maupun garis ibu. ${ }^{16}$ Menurut Otje Salman salah satu cara untuk melihat susunan masyarakat berdasarkan ikatan genealogis adalah terbagi menjadi empat kelompok, yaitu: patrelianial, matrelinial, parental dan alterneteral. ${ }^{17}$ Berdasarkan kondisi struktur masyarakat itulah yang mempengaruhi sikap masyarakat terhadap hak perempuan dalam hukum di indonesia.

Berdasarkan uraian di atas maka upaya untuk penyetaraan posisi hak perempuan dalam kedua hukum tersebut bisa melalui pendekatan kultural atau dengan jala fi melakukan kajian kritis terhadap konsepkonsep pemikiran yang dianggap sebagai sumber hukum Islam. Tentu saja di antara dua cara tersebut yang lebih ringan risikonya adalah melakukan kajian kritis terhadap konsep hak perempuan dibanding dengan merubah kultural. Sebab konsep hak perempuan yang kontroversi dalam hukum Islam di Indonesia yang sudah berkembang bertahun-tahun adaiah bersumber dari pemikiran (ijtihad) para ulama terdahulu yang sudah hidup berabad-abad, sedangkan hasil

${ }^{15}$ Otje Salman, Kesadaran Hukum Masyarakat terhadap Hukum Waris, Ctk. 1, (Bandung: Alurni, 1993), hilm. 48

${ }^{16}$ Abdullah Siddik, Hukum Waris Islam dan Perkembangannya di Seluruh Dunia Islam, Ctk. Pertama, (Jakarta: Wijaya, 1984), hlm. 1.

"Baca Otje Salman, loc.cit, Patrelinial adalah penarikan garis keturunan dilakukan terhadap klan pihak bapak, sedang mairelinial merupakan kebalikan patrelinial, penarikan garis keturunan terhadap klan pihak ibu. Pada susunan Parental penarikan garis kelurunan dilakukan terhadap kedua pihak. Pada susunan alterneteral penarikan garis keturunan dilakukan terhadap klan pihak bapak dan ibu secara berganti-ganti. Susunan masyarakat tersebut dijumpai pada masyarakat Indonesia bagian Timur. 
pemikiran (ijtihad) bersifat terbuka, yaitu mempunyai sifat berkembang. ${ }^{18}$

Upaya yang ditempuh dalam rangka memberi perlindungan hukum bagi perempuan dalam bidang perkawinan dan kewarisan di Indonesia menempuh cara kedua adalah mengadakan pembaharuan hukum Islam dengan cara melakukan kajian kritis terhadap hasil pemikiran (ijtihad) para pemikir hukum Islam terdahulu dengan cara membuat kodifikasi hukum.

Keinginan untuk mengadakan pembaharuan hukum Islam di Indonesia seperti halnya juga di negara-negara Islam di Timur Tengah, di antaranya Mesir (1927). dengan RUU poligami yang kemudian diveto oleh Raja Fu'ad dan perkembangan untuk pembaharuan hukum yang $\operatorname{lain}^{19}$ adalah dalam kerangka pembatasan tindakan laki-laki dalam perkara perkawinan dan perlindungan hak perempuan dalam perkara kewarisan. ${ }^{20}$

Di Indonesia tuntutan pembaharuan hukum Islam, berkaitan dengan positivisasi hukum Islam (kodifikasi hukum Islam) dalam satu buku (kitab) yang akan diberlakukan secara nasional. Langkah ini ternyata juga telah dilakukan oleh negara-negara Asia Tenggara seperti, Malaysia, Singapura, Filipina dan Thailand. ${ }^{21}$ Langkah ini sangat beralasan, sebab selama ini hukum Islam baru tersebar ke dalam kitab-kitab (kitab kuning) secara terpisah-pisah (belum terkodifikasi). Sebagaimana diketahui bahwa kitab-kitab kuning yang tersebar demikian setidak-tidaknya terdapat beberapa kelemahan di antaranya adalah: (1) buku fiqh tersebut masih mengandung perbedaan pendapat baik di kalangan ulama yang semadzhab maupun yang berbeda madzhab;:22 (2) buku figh tersebut merupakan produk hasil ijtihad ahli hukum Islam (ulama) bangsa Arab yang sudah berabad-abad sehingga sifat kompleksitas permasalahan yang dihadapi (pada saat itu) akan jauh berbeda dan kurang konteks dengan perkembangan kebutuhan maupun permasalahan saat ini; (3) fiqh merupakan produk hukum yang kadang bersifat subjektif ${ }_{2}^{23}$ sebab tidak jarang sebuah keputusan hukum dipengaruhi oleh kepentingan individu atau kelompok masing-masing, sehingga bisa dimungkinkan penerapan hukum terhadap suatu kasus tertentu yang sama dapat berbeda bukan karena teksnya melainkan karena perbedaan kepentingan. ${ }^{24}$ Kelemahan itulah yang menjadi sebab kesulitan masyarakat muslim untuk menggunakan fiqh sebagai sumber hukum terhadap penyelesaian kasus-kasus tertentu yang dihadapi.

\footnotetext{
${ }^{19}$ Ahmad Sukardja, op. cit., hlm. 13.

J.N.D. Anderson, op. cit., hlm. 59-67.

2 Ibid., hilm. 49-56.

${ }^{21}$ Sudirman Tebba, Perkembangan Mutakhir Hukum Islam di Asia Tenggara Studi Kasus Hukum Keluarga dan Pengkodifikasiannya, Ctk. Pertama, (Bandung: Mizan, 1993), hlm. 22-23.

22 lbid, him. 19-22.

${ }^{23}$ Abdul Jamil, "Waris Pengganti sebagai Penyelesaian Waris Isiam di Indonesia," dalam Jumal Hukum No.
} 22. Vol. 10. 2003, hlm. 179.

${ }^{24}$ Ahmad Minhaji, "tradisi ljtithad dalam Islam (Dulu, Kini, dan Masa Mendatang)," dalam Jumal Hukum, No. 17. Vol. 8 (2001), him. 14. 
Usaha positivisasi (pembaharuan) hukum Isiam di Indonesia yang terkait dengan bidang hukum perkawinan dan kewarisan ini telah dituangkan ke dalam beberapa peraturan perundang-undang, yaitu: (1) Undang-undang No. 1 Tahun 1974 tentang Perkawinan; (2) PP No. 9 Tahun 1975 Pelaksanaan Undangundang No. 1 Tahun 1974; (3) PP No. 10 Tahun 1983 tentang Izin Perkawainan dan Perceraian bagi Pegawai Negeri Sipii; (4) PP 45 Tahun 1990 tentang perubahan atas PP No. 10 Tahun 1983 tentang Izin Perkawinan dan Perceraian bagi Pegawai Negeri Sipil; (5) Undang-undang No. 7 Tahun 1989 tentang Peradilan Agama; dan (6) Inpres No. 1 Tahun 1991 tentang Kompilasi Hukum Islam (KHI). Peraturan perundang-undangan tersebut merupakan pembaharuan-pembaharuan terhadap hakhak perempuan dalam hukum Islam di bidang perkawinan dan kewarisan .

\section{Hak Perempuan dalam Hukum Perkawinan Islam di Indonesia}

Dalam pandangan ulama modern, perkawinan tidak dapat putus begitu saja atas kehendak laki-laki sepihak (talak). Berbeda dengan pandangan ulama klasik atau konservatif, bahwa kapan saja dan di mana saja jika suami menghendaki talak apakah tegas atau samar-samar-maka perceraian terjadi. Menurut Undang-undang No. 1 Tahun 1974, Pasal 39 ayat (1) bahwa perceraian hanya dapat dilaksanakan di depan sidang pengadilan setelah pengadilan yang bersangkutan berusaha dan tidak berhasil mendamaikan kedua belah pihak. Ketentuan ini dipertegas juga dalam Pasal 65 Undangundang No. 7 Tahun 1989 dan Pasal 129 KHI, bahwa perceraian hanya dapat dilakukan di depan sidang Pengadilan setelah Pengadilan yang bersangkutan berusaha dan tidak berhasil mendamaikan kedua belah pihak. Bahkan Pasal $130 \mathrm{KHI}$ mempertegas bahwa Pengadilan Agama dapat mengabulkan atau menolak permohonan tersebut, dan terhadap keputusan tersebut dapat diminta upaya hukum banding dan kasasi.

Dalam hukum Islam di Indonesia, hak bercerai telah menjadi hak laki-laki (suami) dan perempuan (istri), bahkan dalam praktik persoalan perceraian yang dilakukan oleh seorang istri hanya sekedar membayar uang iwadl Rp 10.000 (sepuluh ribu rupiah) yang dahulu hanya $\mathrm{Rp} 1000$, (seribu rupiah), yang digunakan sebagai tebusan terhadap talak seorang suami. Hal ini berbeda dengan ceri. talak di mana seorang istri dapat menggugat muth'ah dan lain sebagainya, yang besamya sesuai dengan kemampuan suaminya. Kalau suaminya orang berada maka biaya muth'al: juga besar. Sehingga ketentuan ini menghapus anggapan suami yang menggunakan faham (klasik) bahwa kalau seoarang suami tidak mentalaknya maka perceraian seorang istri tidak bisa terjadi.

Dari ketentuan tersebut di atas jelas bahwa seorang suami (laki-laki) tidak dapat semaunya menceraikan istrinya meskipun ia mempunyai hak talak. Ketentuan undang-undang tidak menarik hak talak itu dari kekuasan suami, tetapi demi kemasalahatan, pelaksanaan hak talak itu harus dibatasi (diawasi) oleh hukum dengan cara suami harus meminta izin kepada negara mélalui Pengadilan Agama sebagai bentuk perlindungan terhadap istri (perempuan). Izin mentalak istri itupun setelah ada proses pemeriksaan, apakah suami dapat diberikan izin atau tidak, bahkan di dalam ketentuan Pasal 70 ayat (6) Undang-undang 
No. 7 Tahun 1989 jo. Pasal 131 ayat (4) KHI izin itupun dibatasi jangka waktunya yaitu 6 (enam) bulan sejak ditetapkan hari sidang penyaksian ikrar talak. Apabila dalam tenggang waktu 6 (enam) bulan tersebut suami tidak mengikrarkan talaknya di depan sidang pengadilan secara sah atau patut, maka izin yang diberikan pengadilan tersebut menjadi gugur sehingga suami istri tersebut tetap belum dianggap cerai. Ketentuan Pasal 70 ayat (6) tersebut merupakan bentuk perlindungan hukum negara terhadap istri (perempuan) agar jangan sampai seorang istri terkatung-katung akibat keputusan atau sikap perilaku suami (laki-laki) yang cenderung ingin menambah penderitaan dan mempersulit urusan bekas istrinya untuk dapat menikah dengan laki-laki lain.

Berkaitan dengan perceraian, dalam Undang-undang No. 7 Tahun 1989 diatur mengenai kompetensi relatif pengadilan yang berwenang menangani perceraian (Pasal 73). Dalam Pasal 73 tersebut ditentukan bahwa kompetensi relatif Pengadilan Agama yang berwenang secara relatif adalah Pengadilan Agama yang mewilayahi domisili penggugat (istri) berada. Ketentuan ini menunjukkan adanya perlindungan bagi seorang istri (perempian) yang sangat berlebihan, sebab ketentuan di dalam Pasal 73 ayat (1) Undangundang No. 7 Tahun 1989 merubah ketentuan Hukum Acara Perdata yang berlaku sebagai bagian dari sumber hukum acara di Pengadilan Agama. Ketentuan mengenai. kompetensi relatif suatu pengadilan dalam Hukum Acara Perdata diatur dalam Pasal 118 ayat (1). Pasal 142 ayat (1) Het Herzeine
Indonesisch Reglement (HIR) dan Recht Reglement voor de Buitengewesten (Rbg). Menurut ketentuan pasal tersebut, gugatan diajukan di pengadilan yang mewilayahi tempat tinggal tergugat bukan pada pengadilan yang mewilayahi penggugat. ${ }^{25}$

Masalah lain yang dalam perspektif hukum Islam masih mengandung kontroversi adalah masaiah pernikahan yang dilakukan oleh wanita hamil. Dalam Pasal $53 \mathrm{KHI}$ dijelaskan bahwa wanita hamil di luar nikah dapat dikawinkan dengan pria yang menghamilinya tanpa menunggu anak yang dikandungnya lahir, bahkan tidak perlu dilakukan perkawinan ulang setelah anak yang dikandung lahir. Ketentuan ini sangat melindungi hak-hak perempuan dan anak yang tidak tahu-menahu dosa yang dilakukan oleh ayah dan ibunya. Ketentuan ini mengikis hukuman kepada perempuan yang hamil, di mana menurut hukum Islam (klasik) penderitaan itu dibebankan kepada perempuan meskipun buah dari janin yang dikandung itu dilakukan dengan suka sama suka. Hal ini sejalan dengan ketentuan surat an-Nur ayat (3) di mana dijelaskan bahwa laki-laki tidak boleh nikah kecuali dengan pasangan berzinanya, demikian juga seorang wanita tidak boleh menikah kecuali dengan laki-laki yang menzinahinya.

\section{Hak Perempuan dalam Hukum Waris Islam di indonesia}

Sebagaimana diketahui bahwa hukum waris Islam yang berlaku di Indonesia selama ini adalah hukum Islam yang menganut

${ }^{25}$ Baca Soedikno Mertokusumo, Hukum Acara Perdata, Edisi kelima, (Yogyakarta:Liberty, 1992), hlm.65 
paham Ahiussunnah yang bermadzhab Syafi'i, ${ }^{26}$ di mana dalam menyelesaikan persoalan kewarisan menyangkut ahli waris perempuan dari keturunan perempuan kedudukannya lemah dibanding laki-laki.. ${ }^{27}$ Oleh karenanya keturunan perempuan dari perempuan dimungkinkan selamanya tidak mendapatkan hak waris dari kerabatnya. Hal ini dianggap tidak adil, karena bisa jadi keturunan perempuan dari perempuan yang tertutup itu sangat dekat dengan pewaris, tidak dapat bagian warisan karena ditutup oleh ahli waris yang sangat jauh. Contoh cucu atau cicit perempuan dari anak atau cucu perempuan ditutup oleh anak laki-laki, atau cucu laki-laki dari anak laki-laki, atau saudara laki-laki kandung atau seayah dan keturunan lakilakinya ke bawah. A (laki-laki) mempunyai saudara laki-laki seayah bemama B. A menikah dengan gadis bemama $C$ dan dikaruniai satu anak perempuan bernama $D$. $D$ menikah dengan jejaka bemama $E$ dan dikaruniai satu anak perempuan bemama $F$. Demikian halnya $B$ menikah dengan gadis bernama $G$ dan dikaruniai satu anak laki-laki diberi nama $\mathrm{H}$. setelah dewasa $\mathrm{H}$ menikah dengan gadis bernama $\mathrm{K}$ dan dikaruiai satu anak laki-laki bernama L. Pada tahun $2000 \mathrm{~B}$, dan pada tahun $2001 \mathrm{D}$ (anak perempuan $\mathrm{A}$ ) meninggal dunia, pada tahun $2002 \mathrm{H}$ (anak laki-laki B) meninggal dunia. Pada tahun $2003 \mathrm{~A}$. meninggal dunia.

Kasus tersebut di atas apabila diselesaikan menurut sistem hukum kewarisan Islam (klasik) yang berpaham pada Ahlussunnah maka ahli waris yang berhak untuk mendapatkan bagian warisan adalah $C$ selaku istri dari almarhum $A$, dan L (keponakan laki-laki dari anak laki-lakinya saudara laki-laki kandung) atau cucu keponakan laki-laki dari saudara laki-laki kandung, yang bagiannya $\mathrm{C}$ mendapatkan 1/8 sedangkan $\mathrm{L}$ ashabah karena $\mathrm{L}$ adalah keturunan lak-laki dari saudara laki-laki kandung.

Penyelesaian tersebut kalau dilihat dari sisi keturunan (qaraba) dari pewaris A kedudukan $F$ lebih dekat, sebab posisi cucu $F$ adalah cucu perempuan langsung pewaris (A), tetapi karena berasal dari keturunan perempuan maka dia nasabnya lebih jauh di banding $L$ yang berasal dari keturunan laki-laki.

Berangkkat dari pemahaman tersebut ci atas akhirnya hukum kewarisan Islam menerima kritikan bahwa hukum kewarisan Islam dipandang tidak adil, sehingga perlu adanya kajian untuk pembaharuan terhadap hukum kewarisan Islam. Pembaharuan ini semakin menguat karena adanya tuntutan persamaan hak antara laki-laki dan perempuan. Sebagai bahan perbandingan yang sangat ekstrim yang sama-sama dikembangkan para pemikir (ulama) dari Timur Tengah yaitu faham kewarisan Islam Syi'ah. Pendapat Syi'ah berkaitan dengan keturunan perempuan dari perempuan tetap dipandang sebagai ahli waris yang berhak mewarisi harta kerabatnya. ${ }^{28}$

Hasil pembaharuan hukum kewarisan Islam di Indonesia sebagai upaya persamaan hak antara laki-laki dan perempuan dalam

\footnotetext{
${ }^{20}$ Abdullah Siddik, op. cit., him. 23.

${ }^{27}$ Abdul jamil, op. cit., him. 178.

${ }^{28}$ Baca Abduilah Siddik, op. cit., hlm. 24, baca juga Abdul Jamil, op. cit., 181-182.
} 
bidang kewarisan adalah lahirnya $\mathrm{KHI}$ sebagai bentuk ijthad Jama'i'i, ${ }^{29}$ yang memberi posisi keturunan perempuan dari anak perempuan sebagai ahli waris. Ketentuan ini dapat dibaca dalam ketentuan Pasal 185 ayat (1) dijelaskan bahwa ahli waris yang meninggal lebih dahulu dari pada sipewaris maka kedudukannya dapat digantikan oleh anaknya, keculai mereka yang tersebut Pasal 173.

Ketentuan Pasal 185 ayat (1) tersebut dapat difahami bahwa cucu perempuan dari anak perempuan akan mendapatkan bagian warisan dari kakeknya dan tidak ditutup oleh anak laki-laki atau cucu laki-laki dari anak lakilaki karena dia menggantikan kedudukan ibunya yang meninggal terlebih dahulu. Pembaharuan ini nampaknya sejalan dengan ketentuan-ketentuan al-Quran surat an-Nisa ayat (7) yang oleh Hazairin disebut sebagai asas kewarisan bilateral (parental) di mana antara laki-laki dan perempuan mempunyai hak yang sama untuk mewarisi harta peninggalan dari kedua orangtua dan kerabatnya..$^{30}$

Kedudukan cucu perempuan (F) dalam kasus tersebut di atas apabila diselesaikan berdasarkan $\mathrm{KHI}$ maka $\mathrm{F}$ (sebagai cucu perempuan) dari anak perempuan tetap menjadi ahli waris kakeknya dan tidak tertutup oleh L. (anak laki-laki dari saudara seayah). Dengan demikian penyelesaian atas kasus tersebut, ahli waris dari A (kakek F) adalah $C$ (selaku istri) bagiannya $1 / 8, F$ (cucu perempuan Apewaris dari anak perempuan) yang menggantikan kedudukan ibunya bagiannya $1 / 2$, sebab bagian ibunya apabila belum meninggal adalah $1 / 2$. Sedang $L$ mendapatkan sisa harta waris setelah diambil bagian istri dan cucu perempuan dari anak perempuan. Ketentuan bagian tersebut dapat dilihat dalam Pasal 185 ayat (2), yang menjelaskan bahwa bagian waris pengganti tidak boleh melebihi dari bagian ahli waris yang sederajat dengan yang diganti.

Penyelesaian kasus yang didasarkan pada ketentuan $\mathrm{KHI}$ sebagai mana kasus di atas nampak jelas perlindungan hak perempuan dalam persoalan kewarisan, sebab keturunan perempuan dari perempuan tidak dapat ditutup oleh keturunan laki-laki karena adanya ketentuan mengenai waris pengganti.

\section{Simpulan}

Dari uraian di atas dapat disimpulkan bahwa secara konseptual, hukum perkawinan

${ }^{29}$ ljtihad Jama'i atau ijtihad kolektif adalah semacam lembaga hukum Islam Internasional. Di dalamnya menghimpun sejumlah ahli dari berbagai disiplin ilmu. Hukum-hukum yang akan diputuskan lembaga ini terlebih dahulu dilakukan penelitian yang intensif dan netral, tidak dipengaruhi oleh pemerintah dan golongan awam. Baca Yusuf Qordhawi, Muhammad Madani dan Mu'inuddin Qadri, Dasar pemikiran Hukum Islam TaqlidX ljihad, Penerjemah Husein Muhammad, Ctk. Pertama, (Jakarta: Pustaka Firdaus, 1987), hlm. 82. Baca Ahmad Minhaji, "Tradisi ijtihad dalam Islam (Dulu, Kini dan Masa Mendatang)," Jumal Hukum No. 17, Vol.8 (2001), him. 17

${ }^{30}$ Hazairin, Hukum Kewarisan Islam Bilateral Menurut al-Quran dan Hadits (Jakarta: Tintamas, 1982). hlm. 13 Lihat juga Daud Ali dan Habibah Daud, Lembaga-Lembaga Islam di Indonesia (Jakarta: Raja grafindo Persada, 1995), hlm, 102. Idris Djakfar dan Taufik Yahya, Kompilasi Hukum Islam (Jakarta: Pustaka Jaya, 1995), hlm. 29. Sayuti Thalib, Hukum Waris Islam di Indonesia (Jakarta: Bina Aksara, 1987), hlm. 6 
dan kewarisan telah mengalami perubahan yang cukup signifikan sesuai dengan dinamika perubahan masyarakat. Dalam konteks perubahan itu, hukum perkawinan dan kewarisan didekonstruksi dan rekonseptualisasi dengan menempatkan posisi dan periindungan hak perempuan setara dengan kaum laki-laki (keadilan gender). Keseimbangan hak laki-laki dan perempuan yang menurut faham hukum Islam (klasik) tidak seimbang menjadi setara hak-haknya, bahkan dalam hukum acara yang dipergunakan (Undang-undang No. 7 Tahun 1989) sangat menguntungkan perempuan.

Pembaharuan hukum islam di Indonesia yang dihasilkan dari ljtihad Jama'i baik yang berupa Undang-Undang, Peraturan Pemerintah, Instruksi Presiden yang terkenal dengan sebutan Kompilasi Hukum Islam (KHI) dalam bidang hukum perkawinan dan kewarisan sangat memberikan perlindungan kepada perempuan dibanding dengan hukum-hukum Islam (klasik).

\section{Daftar Pustaka}

Ali, Mohammad Daud, dan Habibah Daud, Lembaga-Lembaga Islam di Indonesia, Jakarta: raja Grafika Persada, 1995.

Ali, Mohammad Daud, Hukum Islam Pengatar IImu Hukum dan Tata Hukum Islam di Indonesia, , Ed. 5, Ctk. Ke lima, Jakarta: Raja Grafindo Persada, 1996.

Anderson, J.N.D., Hukum Islam di Dunia Moderen (Islamic Law in the Modern World), (Penterjemah Machnun Husain), Edisi Revisi, Ct . 1, Yogyakarta: Riara Wacana Yogya, 1994.
Basyir, Ahmad Azhar, Hukum Waris Islam, edisi ke IX, Yogyakarta: Fakultas Ekonomi Ull, 1990

Djamali, Adullah, Hukum Islam Asas-asas hukum Islam I, Hukum Islam II, Ctk. I, Bandung: Mandar Maju, 1992.

Haya binti Mubarok Al-Barik, "Mausu'ah AlMar'atiul Muslimah," Ensiklopedi Wanita Muslimah, diterjemahkan oleh Amir Hamzah Fachrudin, Ctk. Pertama, Jakarta: Darul Falah, $1418 \mathrm{H}$.

Jamil, Abdul, "Waris Pengganti sebagai Penyelesaian Waris Islam di Indonesia," Jumal Hukum No. 22, Vol. 10 (2003).

Mas'udi, Masdar F., "Perempuan dalam Wacana Keislaman," dalam Perempuan dan Pemberdayaan Kumpulan Karangan untuk Menghormati Ulang Tahun ke-70 Ibu Saparina Sadli, Penyunting Sumita Notosusanto dan $E$. Kristin Poerwandari, Ctk. Pertama, Jakarta: Yayasan Obor Indonesia, 1997.

Mertokusumo, Soedikno, Hukum Acara Perdata, Edisi kelima, Yogyakarta: Liberty, 1999.

Minhaji, Ahmad, "Tradisi ljtihad dalam Islam (Dulu. Kini, dan Masa Mendatang)," Jumal Hukum, No: 17, Vol. 8 (2001).

Qardhawi, Yusuf, Muhamad Madani dan Mu'inuddin Qadri, Dasar Pemikiran Hukum Islam Taqlid $X$ ljtihad, Penerjemah Husein Muhammad, Ctk. Pertama, Jakarta: Pustaka Firdaus, 1987.

Rasjid, Sulaiman, i !qih Islam, Ctk. Keduabelas, 
Jakarta: Attahirijah, 1955.

Sadli, Saparina, "Pemberdayaan Perempuan dalam Perspektif Hak Asasi Manusia" dalam Tapi Omas Ihromi DKK, Penghapusan Diskriminasi terhadap Wanita, Edisi pertama, Ctk. 1, Bandung; Alumni, 2000.

Salman, Otje, Kesadaran Hukum Masyarakat Terhadap Hukum Waris, Ctk. 1, Bandung: Alumni, 1993.

Siddik, Abdullah, Hukum Waris Islam dan Perkembangannya di Seluruh Dunia Islam, Ctk. Pertama, Jakarta: Wijaya, 1984.
Sudarsono, Pokok-Pokok Hukum Islam, Ctk. Pertama, Jakarta: Rineka Cipta, 1992.

Sukardja, Ahmad, Piagam Madinah dan Undang-Undang Dasar 1945: kajian PerbandinganTentang Dasar Hidupersama Dalam Masyarakat Yang Majemuk, Jakarta: UI Press, 1995.

Taher, Hadari Djenawi, Pokok-Pokok Pikiran Dalam U.U. Preadilan Agama, Jakarta: Alda, 1989.

Tebba, Sudirman, Perkembangan Mutakhir Hukum Islam di Asia Tenggara Studi Kasus Hukum Keluarga dan Pengkodifikasiannya, Ctk. Pertama, Bandung: Mizan, 1993.

808080 